\title{
Response of upland taro 'Blanca' to sett size and plant spacing',
}

\author{
Carlos E. Ortiz ${ }^{3}$ and Agenol González-Vélez"
}

J. Agric. Univ. P.R. 83(1-2):33-39 (1999)

\begin{abstract}
The white-fleshed taro cultivar Blanca has been traditionally used in the central mountainous region of Puerto Rico because of its adaptability to low fertility soils, ability to withstand drought periods under rain-fed conditions and its acceptability by local consumers. Blanca belongs to the Colocasia's botanical variety esculenta. Thus, it should be characterized by a large main corm and few cormels. In commercial fields, individual plants usually average more than 10 suckers, a finding which indicates a low harvest index. The objective of this study was to evaluate the effect of practical combinations of sett size and plant spacing on taro Blanca yield and dry matter distribution at harvest. Treatments represented alternatives of practical significance in commercial production. Sett sizes were 57 to $114 ; 170$ to 227; and 284 to $340 \mathrm{~g}$ per sett. Spacing was $38.1,45.7$ and $61.0 \mathrm{~cm}$ between plants. Plants trom the smaller setts have the least dry matter and productivity. Regardless of the sett size, plants grown at 61.0 - and at $45.7-\mathrm{cm}$ spacing differed neither in yield nor in dry weight measurements. Reduction of the planting distance to $38.1 \mathrm{~cm}$ decreased yield and dry weight. The sett size and plant spacing combinations used were not effective in reducing the number of suckers per plant nor in improving the dry matter partitioning into the main corm. Plants averaged 13.8 cormels and had a dry matter partitioning into the main corm of 0.37 . The results support the need for the selection of Colocasia esculenta genotypes for improved partitioning into the commercially important part of the plant.
\end{abstract}

Key words: upland taro, sett size, plant spacing

\section{RESUMEN}

Respuesta de la malanga de secano 'Blanca' al tamaño del material de propagación y a la distancia de siembra

La malanga 'Blanca' se ha sembrado tradicionalmente en la región central de Puerto Rico por su adaptabilidad a suelos de baja fertilidad, a cultivo sin riego suplementario y por su aceptación por los consumidores. De acuerdo con la descripción botánica de la variedad esculenta, Blanca se debe caracterizar por un cormo bien desarrollado y un bajo número de cormelos. Observaciones de campo indican que el número de cormelos es alto, usualmente más de $\mathbf{1 0}$ por planta, lo que resulta en un indice de cosecha

'Manuscript submitted to the Editorial Board 11 February 1998.

${ }^{2}$ The authors are grateful to Luis A. Figueroa for his assistance in carrying out the field activities.

"Associate Plant Breeder. Department of Agronomy and Soils. Agric. Exp. Stn. Univ. of Puerto Rico., P.O. Box 21360, San Juan, Puerto Rico 00927.

${ }^{4}$ Associate Researcher, Department of Horticulture. 
bajo. El objetivo de este estudio fue evaluar el efecto de variaciones en el tamaño del material de propagación (semilla) y en la distancia de siembra sobre el rendimiento y la distribución de materia seca de Blanca. Los tratamientos representaron alternativas prácticas para la producción comercial. Los tamaños del material de propagación fueron de 57 a 114; de 170 a 227 ; y de $\mathbf{2 8 4}$ a $\mathbf{3 4 0} \mathrm{g}$ por semilla. Las distancias entre plantas fueron $38.1,45.7$ y $61.0 \mathrm{~cm}$. Las plantas que provenian del material de propagación más pequeño produjeron menor materia seca y menos rendimiento. Las plantas que crecieron a 61.0 y a $45.7 \mathrm{~cm}$ de distancia no fueron diferentes en peso seco ni en rendimiento. Al reducir la distancia de siembra a $38.1 \mathrm{~cm}$ se redujo el peso seco y el rendimiento. Las combinaciones de tamaño de material de propagación y distancia de siembra no resultaron efectivas en reducir el número de hijuelos ni en aumentar el porcentaje de materia seca en el cormo. En promedio las plantas produjeron 13.8 cormelos con 0.37 del total de la materia seca acumulada en el cormo. Los resultados sostienen la necesidad para la selección de genotipos de Colocasia esculenta con mejor porcentaje de acumulación de materia seca en la parte comercial.

\section{INTRODUCTION}

In Puerto Rico the production of taro (Colocasia esculenta var esculenta) in upland conditions is concentrated in the central mountainous region. Many of the agricultural soils of this region are characterized by low fertility. The steepness of the landscape is also a major constraint for the mechanization of farming operations. In the farming system of the region, supplemental irrigation is generally not available, thus seldom used in the production of tuber crops such as taro. The white-fleshed cultivar: Blanca has been traditionally used under these conditions because of its tolerance to low fertility soils, adaptability to a rain-fed production system and its acceptability by local consumers.

Blanca belongs to the Colocasia's botanical variety esculenta. Cultivars within this botanical variety should be characterized by a large main corm and four to eight small cormels or suckers (Plucknett, 1983). Observations in commercial fields, however, have shown that at harvest Blanca averages more than 10 suckers per plant. Cormels of suckers generally do not attain commercial size; thus, they are discarded or used as propagation material and animal feed. In a field experiment, Goenaga (1995) determined that in Blanca, dry matter partitioning into the cormels of the suckers 201 days after planting (DAP) accounted for more than $50 \%$ of the plant dry weight. He also found an average of 12 suckers per plant. The field observations and the study by Goenaga suggest that Blanca has a relatively low dry matter partitioning into the main corm. In this scenario, the dilemma is to determine whether the yield and the dry matter partitioning into the main corm of Blanca can be increased by managing the sett size and the plant spacing. 
Previous studies evaluating the effect of the size of the propagation material on taro's performance have suggested that larger setts improve the main corm size and thus the yield per individual plant (Dalion et al., 1980; Bourke and Perry, 1976). These studies, however, have been conducted with lowland management systems, which are considerably different from the conditions in which Blanca is produced in Puerto Rico. Using densities varying from 26,000 to 53,000 plants per hectare in upland conditions, Pardales and Belmonte (1984) found that reducing plant spacing reduces main corm size but increase the yield per area. These authors concluded that in upland conditions yield per land area is primarily a function of the number of corms rather than of the size of the individual corm. Densities used in this study, however, are higher than that commonly used for Blanca. None of the previous studies have examined at the same time the combined effect of sett size and plant spacing on taro under upland conditions. The objective of this study was to evaluate the effect of practical combinations of sett size and plant spacing on taro cv Blanca yield and dry matter distribution at harvest.

\section{MATERLALS AND METHODS}

The field activities were conducted on the Agricultural Experiment Station farm of the University of Puerto Rico at Corozal in two consecutive planting seasons. The elevation was $195 \mathrm{~m}$. In the experimental area the soil was an Ultisol of the Corozal series (Aquic Haplohumults) with an average slope of $25 \%$, a $\mathrm{pH}$ of 6.14 and $2.18 \%$ organic matter. In 1995 the experiment was planted 25 May, whereas in 1996 it was planted 20 February. Cormels were used as propagation material (setts). Treatments were chosen to represent practical alternatives in commercial production and consisted of the $3 \times 3$ factorial combination of sett size and plant spacing within the row. The setts were classified into various sizes on the basis of their fresh weight. Sizes were 57 to 114,170 to 227 , and 284 to $340 \mathrm{~g}$ per sett. Setts outside the established ranges were discarded. Spacing was $38.1,45.7$ and $61.0 \mathrm{~cm}$ between plants within the row for densities equivalent to 28,$704 ; 23,930$; and 17,928 plants per hectare, respectively. Plot size was three $9.12-\mathrm{m}$-long rows spaced at $0.91 \mathrm{~m}$. Three replications were used.

All plants were sidedressed with $85 \mathrm{~g}$ of 12-6-16 fertilizer applied in two equally divided portions. In 1995 , plants were sidedressed at 48 and 153 DAP, whereas in 1996 fertilizer was applied at 46 and 134 DAP. Water was applied as needed with a sprinkler irrigation system. Hand hoeing was used for weed control. In 1995, the experiment was harvested $242 \mathrm{DAP}$, whereas in 1996 harvest was performed $223 \mathrm{DAP}$. 
During harvest, two plants per plot were chosen at random from the center row and sampled for fresh and dry weights. The rest of the plants within the plots were harvested for yield. In the samples, the aerial parts were divided into the leaf lamina and leaf petiole. The original planting sett and the roots were removed from the underground parts and discarded. After this procedure, the main corm and cormels were separated. The individual plant parts were weighed for fresh weight. All parts were oven-dried individually at $54.4^{\circ} \mathrm{C}$ for dry weight.

Fresh and dry weights of the individual plant parts and for the entire plant were subjected to correlation analyses. Data for dry weight, number of cormels and yield were analyzed as a split plot. In the analyses, year was considered as the main plot. The subplot was the factorial combination of sett size and plant spacing.

\section{RESULTS AND DISCUSSION}

Fresh and dry weights of the individual plant parts and of the entire plant were significantly correlated $(\mathrm{P} \leq 0.05)$. Correlation coefficients varied from 0.81 for leaf petiole to 0.99 for total plant dry weight. On the basis of the similarity of the data, the dry weight was used for the statistical analyses. Analyses of variance revealed that the main effects -year, sett size and planting distance-were significant for most of the dependent variables. However, neither the three-way nor the two-way interactions among main effects were significant sources of variation.

Plants were larger in 1995. That year plants had more lamina, cormels and combined plant dry weight than plants of 1996 (Table 1). This size increase, however, was not associated with a significant increase in yield. The dry weights of the leaf lamina and the leaf petiole were affected neither by the sett size nor by plant spacing (Table 1). This lack of response of the aerial plant parts to treatments can be associated with time of sampling. Sampling occurred at harvest (more than $220 \mathrm{DAP}$ ) when plants were commercially mature and leaf area was reduced. In taro, leaves (lamina and petiole) grow and senece sequentially. Previous studies have shown reduction in taro's leaf area at harvest (Dalion et al., 1980; Shih and Snyder, 1984). A study performed in Puerto Rico has shown that the onset for leaf area reduction in Blanca occurs approximately at 120 DAP (Goenaga, 1995).

In this study, plants from the smaller setts had the least dry weight and productivity (Table 1). Plants from sett sizes $170 \mathrm{~g}$ and larger did not differ in yield nor in the plant dry weight measurements. Also these plants were larger and better yielders than those from smaller setts. Similar results have been reported by Bourke and Perry (1976) and by Dalion et al. (1980). These growth responses have been attributed to 
the availability of assimilates in the sett. In taro, the sett is the primary source of assimilates for growth during the early stages of plant development (Goenaga, 1995). A study considering sett size associated the availability of assimilates with faster leaf area and plant development and thus with increased yield potential (Dalion et al., 1980).

Regardless of the sett size, plants grown at $61.0-$ and at $45.7-\mathrm{cm}$ spacing did not differ in yield per area nor in plant dry weight measurements (Table 1). Planting at $61.0 \mathrm{~cm}$ will require fewer setts per land area than $45.7-\mathrm{cm}$ spacing. Reduction in planting material may represent savings in costs of the planting material itself and in the costs of planting. However, planting as closely as $45 \mathrm{~cm}$ should result in more leaf area per land area in early stages of the crop cycle and thus rapid canopy closure. Rapid leaf area and crop development has direct implications in capturing solar energy, conserving soil and reducing weed interference (Shih and Snyder, 1984; Lugo et al., 1997). Among treatments, the reduction of the planting distance to the minimum tested decreased yield and total plant dry weight. The use of $38.1 \mathrm{~cm}$ as planting distance also decreased the weight of corms and cormels. Reduction

TABLE 1.-Dry weight at harvest and yield for taro 'Blanca' plants grown from different sett size and plant spacing under upland conditions.

\begin{tabular}{|c|c|c|c|c|c|c|}
\hline \multirow{2}{*}{$\begin{array}{l}\text { Source of } \\
\text { Variance }\end{array}$} & \multicolumn{5}{|c|}{ Dry Weight } & \multirow[b]{2}{*}{ Yield } \\
\hline & Lamina & Petiole & Corm & Cormels & Total & \\
\hline Year & \multicolumn{5}{|c|}{$\ldots \ldots$. $\ldots$ glplant $\ldots \ldots \ldots \ldots \ldots$} & $\mathrm{kg} / \mathrm{ha}$ \\
\hline 1996 & 16.8 & 47.3 & 80.5 & 58.2 & 202.8 & 10,207 \\
\hline 1995 & 52.1 & 73.1 & 154.2 & 184.0 & 463.4 & 15,722 \\
\hline $\operatorname{LSD}_{0.05}$ & 29.2 & NS & NS & 91.3 & 254.8 & NS \\
\hline \multicolumn{7}{|l|}{ Sett size } \\
\hline \multicolumn{7}{|c|}{$\mathrm{g}$ of fresh weight per sett } \\
\hline 284 to 340 & 36.6 & 66.0 & 126.3 & 137.8 & 365.7 & 14,161 \\
\hline 170 to 227 & 35.1 & 61.0 & 125.5 & 125.7 & 348.2 & 13,979 \\
\hline 57 to 114 & 31.6 & 53.6 & 100.1 & 99.8 & 285.1 & 10,753 \\
\hline $\operatorname{LSD}_{0.05}$ & NS & NS & NS & 27.7 & 62.8 & 1,425 \\
\hline \multicolumn{7}{|c|}{$\begin{array}{l}\text { Plant spacingt } \\
\mathrm{cm}\end{array}$} \\
\hline 61.0 & 37.1 & 62.5 & 131.9 & 135.8 & 367.3 & 14,454 \\
\hline 45.7 & 35.0 & 62.1 & 122.0 & 127.6 & 346.7 & 13,448 \\
\hline 38.1 & 31.3 & 56.1 & 98.0 & 99.9 & 285.3 & 10,990 \\
\hline $\mathrm{LSD}_{0.05}$ & NS & NS & 27.4 & 27.7 & 62.8 & 1,425 \\
\hline
\end{tabular}

'Distance between plants within the row. 
in taro's plant dry weight and corm size as a response to less than optimum planting distance has been previously reported by Pardales and Belmonte (1984).

On the basis of the results of this study, to obtain the local standards of yield per unit of land, growers should use setts heavier than $170 \mathrm{~g}$ of fresh weight and planting distance of at least $45.7 \mathrm{~cm}$ (Table 1). Longer spacing within the row should result in larger corms. In spite of these yield responses, neither sett size nor plant spacing evaluated in this study had a significant effect on number of suckers per plant nor on the percentage of dry matter partitioning into the corm at harvest. Thus, other management practices must be analyzed as strategies to improve the dry matter partitioning into the corm. Over the two years, the number of cormels was highly variable with an average of $13.8 \pm 6$ SD (standard deviation) per plant. The average dry matter partitioning into the corm was $0.37 \pm 0.08 \mathrm{SD}$. The partitioning to the other plant parts was $0.10 \pm 0.02 \mathrm{SD}$ into the leaf lamina, $0.19 \pm 0.05 \mathrm{SD}$ into the petiole and $0.34 \pm 0.09 \mathrm{SD}$ into the cormels. The dry matter partitioning into the main corm obtained in this study was higher than the $0.30 \mathrm{ob}-$ tained previously for Blanca by Goenaga (1995). However, our study did not consider root dry weight, which, according to Goenaga and Chardón (1995), may represent close to $4 \%$ of the total plant dry weight. In this study, with any planting distance or with setts heavier than $170 \mathrm{~g}$, the corm/cormels dry weight ratio at harvest was less than one (Table 1). Therefore, at the end of the growing season, dry matter partitioning into the non commercial underground part was greater than into the commercial part. The above results support the need for the selection of Colocasia esculenta genotypes for improved partitioning into the commercially important part of the plant as suggested by Waaijenberg and Aguilar (1994) and Goenaga (1995).

\section{LITERATURE CITED}

Bourke, R. M. and C. H. Perry, 1976. Influence of sett size on the growth and yield of taro (Colocasia esculenta). Papua New Guinea Agric. J. 27(4):115-120.

Dalion, S. S., J. R. Pardales, Jr. and M. E. Baliad, 1980. Effect of sett size on the growth, development and yield of taro. Ann. Trop. Res. 10(2):121-125.

Goenaga, R., 1995. Accumulation and partitioning of dry matter in taro [Colocasia esculenta (L.) Schott]. Ann. Bot. 76:337-341.

Goenaga, R. and U. Chardón, 1995. Growth, yield and nutrient uptake of taro grown under upland conditions. J. Plant Nutrition 18(5):1037-1048.

Lugo, M. de L., C. E. Ortiz and A. González, 1997. Leaf area index related to weed suppression in upland taro. J. Agric. Univ. P. R. 81(3-4);219-221.

Pardales, J. R., Jr. and D. V. Belmonte Jr., 1984. Cultural management studies on upland taro: Effects of population density and planting method on growth and yield. Philipp. J. Crop Sci. 9(1):29-32. 
Plucknett, D. L., 1983. Taxonomy of the genus colocasia. p. 14-19. In: J. K. Wing (ed.), Taro: A review of Colocasia esculenta and its potentials. Univ. of Hawaii Press. Honolulu, HI.

Shih, S. F. and G. H. Snyder, 1984. Leaf area index and dry biomass of taro. Agron. J. 76 (3):750-753.

Waaijenberg, H. and E. Aguilar, 1994. Production and partitioning of dry matter in eddoe (Colocasia esculenta var antiquorum). Trop. Agric: 71(1):49-56. 